\title{
Multi-method observation and analysis of a tsunami caused by glacier calving
}

\author{
Martin P. Lüthi and Andreas Vieli \\ Institute of Geography, University of Zurich, 8057 Zurich, Switzerland \\ Correspondence to: M. P. Lüthi (martin.luethi@geo.uzh.ch)
}

Received: 19 October 2015 - Published in The Cryosphere Discuss.: 23 November 2015

Revised: 11 April 2016 - Accepted: 23 April 2016 - Published: 12 May 2016

\begin{abstract}
Glacier calving can cause violent tsunami waves which, upon landfall, can cause severe destruction. Here we present data acquired during a calving event from Eqip Sermia, an ocean-terminating glacier in west Greenland. During an exceptionally well-documented event, the collapse of $9 \times 10^{5} \mathrm{~m}^{3}$ ice from a $200 \mathrm{~m}$ high ice cliff caused a tsunami wave of $50 \mathrm{~m}$ height, traveling at a speed of $25-33 \mathrm{~m} \mathrm{~s}^{-1}$. This wave was filmed from a tour boat at $800 \mathrm{~m}$ distance from the calving face, and simultaneously measured with a terrestrial radar interferometer and a tide gauge. Tsunami wave run-up height on the steep opposite shore at a distance of $4 \mathrm{~km}$ was $10-15 \mathrm{~m}$, destroying infrastructure and eroding old vegetation. These observations indicate that such high tsunami waves are a recent phenomenon in the history of this glacier. Analysis of the data shows that only moderately bigger tsunami waves are to be expected in the future, even under rather extreme scenarios.
\end{abstract}

\section{Introduction}

Subaerial mass movement into water, such as landslides, pyroclastic flows, and glacier calving, produce tsunami waves that travel for long distances, producing high wave runups on shorelines, and causing disasters far away from the generation area (e.g., Walder et al., 2003; Fritz et al., 2003). Glacier calving, as well as rotating icebergs in fjords, can trigger large tsunami waves which have the potential to threaten lives and cause damage on the coasts (e.g., MacAyeal et al., 2011; Levermann, 2011).

In Greenland, long period waves caused by glacier calving are a common phenomenon in narrow fjords, where they affect shores at large distance from the glaciers (e.g., Reeh,
1985). In extreme cases, harbors have been destroyed by tsunamis from capsizing icebergs (video on YouTube, http:// www.youtube.com/watch?v=XY7Y313BUBA), and fishing boats as well as tourist vessels have been threatened by such waves (MacAyeal et al., 2011).

Glacier calving is a sudden fracture phenomenon that releases large amounts of ice during short-lived events. The release of ice happens in different modes (Benn et al., 2007): ice front collapse, chunks breaking off, subaqueous calving, and full-thickness iceberg rotation (Amundson et al., 2008; Nettles et al., 2008). For example, full-thickness calving events observed at Jakobshavn Isbræ (west Greenland) caused initial wave heights of tens of meters due to the vertical iceberg oscillations of $70 \mathrm{~s}$ period (Lüthi et al., 2009). Wave heights can still far exceed $1 \mathrm{~m}$ at $3 \mathrm{~km}$ distance, with dominant periods of 30-60 s (Amundson et al., 2010, and unpublished pressure sensor data from different locations in the Kangia ice fjord). Such calving waves cause lowfrequency seismicity that is detectable at up to $150 \mathrm{~km}$ distance (Amundson et al., 2012; Walter et al., 2012, 2013). Calving-induced seismicity from full-thickness calving has even been observed on the global seismic network as slow seismic events, sometimes termed "glacial earthquakes" (Ekström et al., 2003, 2006; Amundson et al., 2008; Nettles et al., 2008).

Here, we document and analyze a tsunami caused by the collapse of a $200 \mathrm{~m}$ high ice cliff of a calving outlet glacier of the Greenland Ice Sheet. This event was filmed by tourists on a boat in close vicinity of the calving front, and was simultaneously measured with a terrestrial radar interferometer and a high-frequency tide gauge. 


\section{Study site}

Eqip Sermia $\left(69^{\circ} 48^{\prime} \mathrm{N}, 50^{\circ} 13^{\prime} \mathrm{W}\right.$; Fig. 1) is a medium size outlet glacier on the west coast of the Greenland Ice Sheet. The terminus area is about $4 \mathrm{~km}$ wide and terminus flow speed was about $3 \mathrm{~m} \mathrm{day}^{-1}$ during the last century, corresponding to a calving flux of $\sim 0.8 \mathrm{~km}^{3} \mathrm{a}^{-1}$ (Bauer, 1968). After a century of slowly varying terminus positions, a slow retreat and acceleration started in 2000, and flow velocities accelerated to $14 \mathrm{~m} \mathrm{day}^{-1}$ in 2014 (Lüthi et al., 2016). In 2014, the calving front reached $150-200 \mathrm{~m}$ height in the northern terminus lobe. This high calving front formed around 2012 and induced calving events that lead to $15 \mathrm{~m}$ tsunami waves upon landfall which had not been observed before, and which destroyed the boat landing of a local tourist operation.

\section{Methods}

\subsection{Terrestrial radar interferometer}

A terrestrial radar interferometer (TRI; Caduff et al., 2014) was used in summer 2014 to measure ice flow velocities of the terminus area. The TRI system was a Gamma Portable Radar Interferometer (GPRI), a Ku-band real aperture radar with one transmitter and two receiver antennas. Measurements of radar intensity and phase were recorded in $1 \mathrm{~min}$ intervals for 5 consecutive days.

Topographic information can be extracted from interferograms generated from the radar signal of the two receiving antennas. The topographic phase of the radar signal, obtained with the Gamma Radar Software Suite, is transformed into elevation at radar azimuth and range to provide a digital elevation model (Strozzi et al., 2012). The elevations derived in this way differ from the Greenland Ice Mapping Project (GIMP) digital elevation model (GIMPDEM; Howat et al., 2014) on stable terrain by less than $5 \mathrm{~m}$ on slightly inclined areas, but can exceed $20 \mathrm{~m}$ on steep terrain.

\subsection{Tide gauge}

A tide gauge was installed in the fjord opposite the Eqip Sermia calving front (position marked in Fig. 1). The tide gauge consisted of a miniature MSR 165 data logger with a pressure sensor, sampling data in $5 \mathrm{~s}$ interval with an accuracy of $\pm 2.5 \mathrm{mbar}$, or $\pm 2.5 \mathrm{~cm}$ water level. The logger was mechanically protected within a $40 \mathrm{~cm}$ long steel pipe, and suspended on a steel cable mounted on a rock with anchor bolts. Average depth of the sensor below sea level was $3 \mathrm{~m}$.

\section{Results}

Collapses of the $200 \mathrm{~m}$ high glacier front which lead to big tsunami waves at the opposite shore have been observed

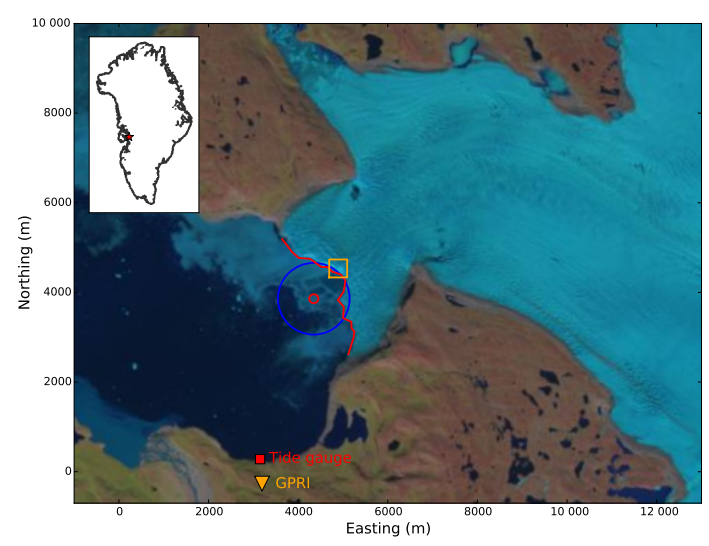

Figure 1. Satellite image (Landsat, 3 July 2014) illustrating the positions of the glacier calving front (red line) and the locations of TRI and the tide gauge. The orange square shows the part of the ice front that collapsed on 2 July 2014. The position of a tour boat during the ice front collapse is indicated by a red circle; the blue circle marks $800 \mathrm{~m}$ distance from the boat. (Polar Stereographic projection, offsets with respect to 206000,2206000 .)

since 2012, and happen roughly every week during the summer. One such event happened on 2 July 2014 when a tour boat was in proximity of the glacier terminus. The ice front collapse and the ensuing tsunami wave were filmed by several passengers on the tour boat (video on YouTube, https:// www.youtube.com/watch? $\mathrm{v}=\mathrm{Cxd}-\mathrm{jA}$ A_QIM). The exact position of the boat was determined by analysis of the TRI intensity data on which the boat is clearly visible as a bright spot which moves against the ocean currents (the position at 14:06 UTC is marked with a red circle in Figs. 1 and 2). During impact of the ice mass the boat was at a distance of $800 \mathrm{~m}$ from the glacier terminus (blue circle in Figs. 1 and 2). From the TRI data we can bracket the time of the collapse between 14:06 and 14:07 UTC (no accurate timing is available for the video). In the following we determine the ice slide volume, the tsunami wave celerity, the height of the wave, the water depth in the impact area, and the height of the tsunami wave at the tide gauge on the opposite coast.

\subsection{Slide geometry and volume}

The geometry of the ice front and the volume of the collapsed part was determined from digital elevation models (DEMs) measured with the TRI instrument. The geometry of the calving front is shown in Fig. 3 along a longitudinal transect (marked in Fig. 4). Between 14:06 and 14:07 UTC the ice thickness changed by about $100 \mathrm{~m}$ in the vertical, which corresponds to a surface-parallel ice slab thickness of $s=50 \mathrm{~m}$.

The thickness change between the DEMs from 14:06 and 14:07 UTC, i.e., before and after the collapse, is shown in Fig. 4. Spatial integration of the thickness change within the collapse zone yields an ice slide volume of $V_{\mathrm{s}}=9 \times 10^{5} \pm 3 \times 10^{4} \mathrm{~m}^{3}$. 

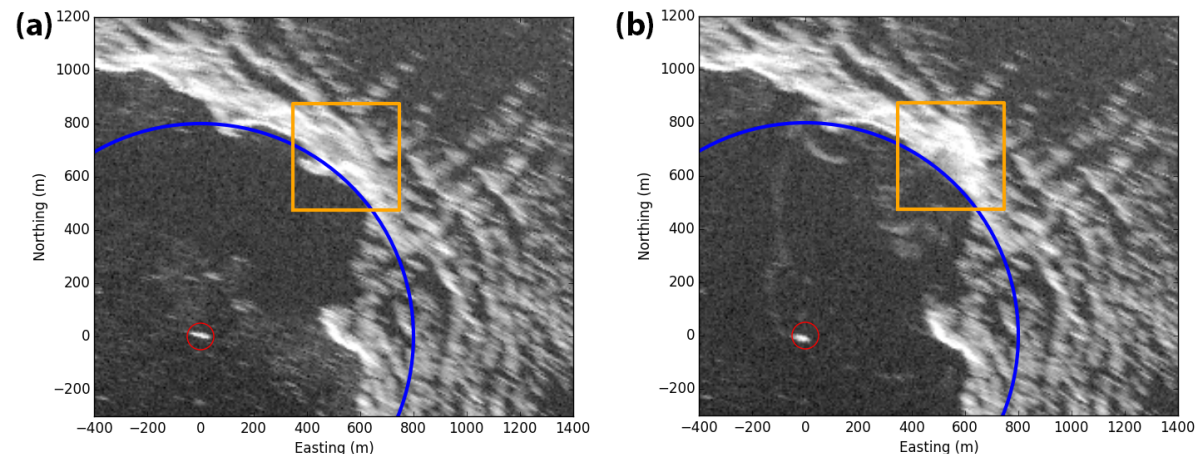

Figure 2. Radar signal intensity (MLI) plots of the glacier with the collapsed ice front (orange frame), the location of the tour boat (red circle), and a circle of $800 \mathrm{~m}$ distance from the tour boat (blue). (a) Before the collapse (14:06 UTC), (b) after the collapse (14:07 UTC). Well visible in frame (b) is the crest of the tsunami wave that reaches the tour boat. The coordinate system is centered on the tour boat.

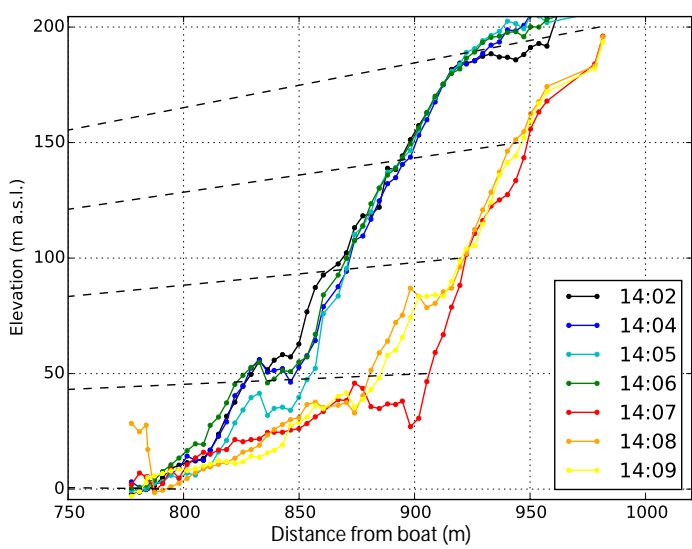

Figure 3. Calving front geometry change during the ice front collapse measured with the TRI. The glacier surface is shown along a profile indicated in Fig. 4. The ice front collapse happened between 14:06 and 14:07 UTC. The dashed black lines indicate rays starting from the tour boat, and are used to determine the height of features in Fig. 5.

\subsection{Slide impact velocity}

The velocity of the falling ice mass upon impact on the water can be estimated with conservation of energy. Assuming that the potential energy of the center of the falling mass is converted into kinetic energy, and assuming a friction coefficient $f$, yields (Fritz et al., 2004, Eq. 18)

$v_{\mathrm{S}}=\sqrt{2 g \Delta z(1-f \cot \alpha)}$,

where $g=9.81 \mathrm{~m} \mathrm{~s}^{-2}$ is the acceleration due to gravity. With an initial center-of-mass elevation of $\Delta z=100 \mathrm{~m}$ (half the ice front height), a slope $\alpha=45^{\circ}$, and a friction coefficient of $f=0.2-0.1$, the impact velocity is $v_{\mathrm{s}}=39-42 \mathrm{~m} \mathrm{~s}^{-1}$. This choice of the friction parameter is motivated by studies of dynamic friction of ice on ice at high temperature and speed (Schulson and Fortt, 2012).

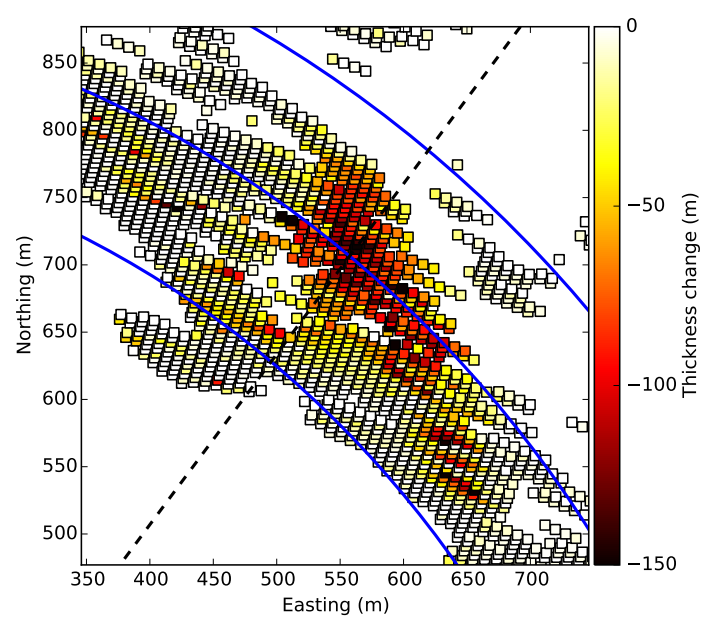

Figure 4. Thickness change during the ice front collapse measured with the TRI. The vertical difference between two DEMs before and after the event (14:06 and 14:07 UTC) is shown. Blue circles are in 800,900 , and $1000 \mathrm{~m}$ distance from the tour boat. The dashed line indicates the location of the profiles shown in Fig. 3.

An independent estimate of the ice slide impact velocity can be gained directly from analysis of the video. Vertical motion of the falling ice between two video frames is roughly 1.5 pixels, with a time difference of $1 / 30 \mathrm{~s}$ between frames. With the known height of the calving face of $200 \mathrm{~m}$ and its geometry, illustrated in Figs. 3 and 5, we can determine that 73 pixels correspond to $50 \mathrm{~m}$ vertical distance. Therefore, we obtain a vertical velocity of the falling ice above the impact zone of $\sim 30 \mathrm{~m} \mathrm{~s}^{-1}$. Since the ice moves along a $45^{\circ}$ slope towards the observer, this number has to be multiplied by a factor $\sqrt{2}$. The thus determined impact velocity is again $v_{\mathrm{s}}=42 \mathrm{~m} \mathrm{~s}^{-1}$.

\subsection{Tsunami wave celerity}

The average celerity (wave crest velocity) of the tsunami wave can be determined from the video. The time interval 


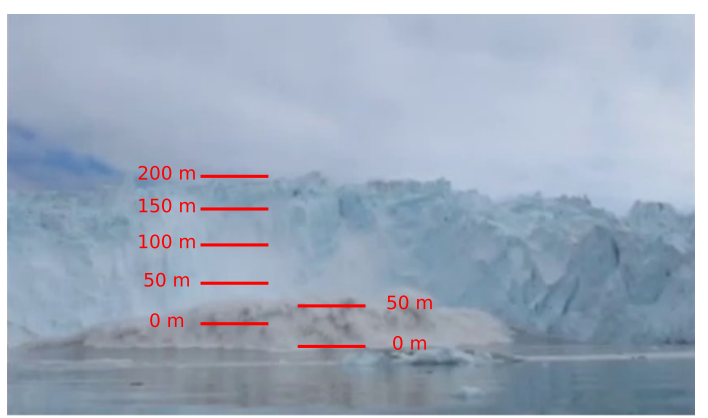

Figure 5. Video still of the tsunami wave taken from the tour boat at $800 \mathrm{~m}$ distance of the terminus. The tsunami wave bore reaches a maximum wave crest height of $50 \mathrm{~m}$. The red horizontal lines indicate the projection of the calving front (black dashed lines in Fig. 3) to a distance of $600 \mathrm{~m}$ from the tour boat.

between the beginning of wave formation and the moment when the wave reaches the boat is about 30-35 s (both times cannot be determined exactly). The distance traveled during this time is $800 \mathrm{~m}$ (the distance between tour boat and calving front determined with the TRI; blue circle in Fig. 2). The initial wave celerity, averaged over the first $800 \mathrm{~m}$ distance, therefore is $c=22-26 \mathrm{~m} \mathrm{~s}^{-1}$.

At the boat landing on the shore opposite the glacier, traditionally called "de Quervain's Havn" or "Port Emile Victor", the water level was measured in $5 \mathrm{~s}$ interval with a pressure sensor. This sensor was located at a distance of $4550 \mathrm{~m}$ of the collapsed part of the ice front, or $3750 \mathrm{~m}$ from the tour boat. The tsunami wave reached this shore at 14:09:08 and thus about $160 \mathrm{~s}$ after the collapse. From the TRI intensity file (Fig. 2b) we can determine that the wave arrived at the boat at 14:07:11, given the accurate timing and angular velocity of the radar. Therefore the first wave crest traveled between boat and pressure sensor in $117 \mathrm{~s}$ with an average speed of $32 \mathrm{~m} \mathrm{~s}^{-1}$. This is equal to the theoretical speed of a solitary wave with wave crest amplitude (height above undisturbed sea level) $a_{\mathrm{c}}$ in water of $h=110 \mathrm{~m}$ depth (Heller et al., 2008, Eq. 7).

$c=\sqrt{g\left(h+a_{\mathrm{c}}\right)}$

This water depth estimate agrees well with depth soundings in the fjord which are mostly in the range 100-150 m (Lüthi et al., 2016).

\subsection{Maximum tsunami wave height}

The maximum height of the tsunami wave can be approximately determined from video stills. The calving front geometry is known from the TRI DEMs and reaches $200 \mathrm{~m}$ (Figs. 3 and 5). The horizontal position of the wave crest can be calculated from the initial wave celerity determined above. The maximum wave crest height is reached about $11 \mathrm{~s}$ after the slide mass enters the water, and therefore at a distance of $x_{\mathrm{M}}=240-280 \mathrm{~m}$ from the glacier terminus. The maximum

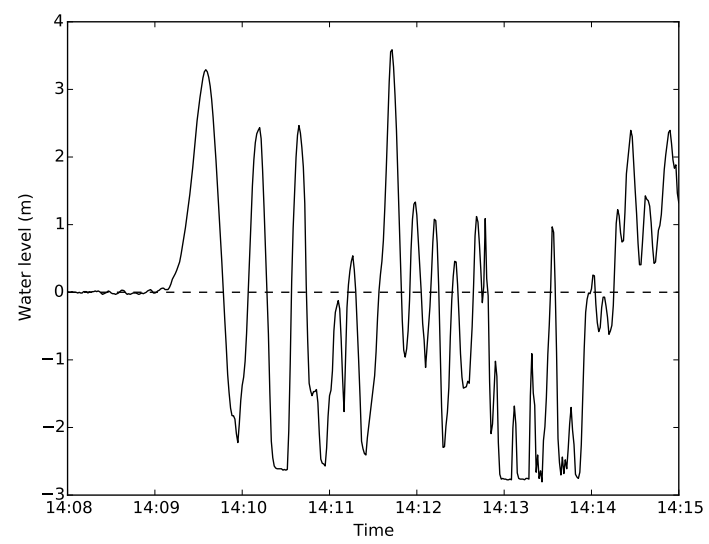

Figure 6. The tsunami wave height at the shore opposite of the glacier measured with a pressure sensor.

wave height is now determined from simple geometrical considerations (illustrated in Fig. 3). The highest crest height (amplitude) of the tsunami wave thus determined is $a_{\mathrm{M}}=45$ $50 \mathrm{~m}$, as shown in Fig. 5.

The wave period in the impact zone is $T \sim 16 \mathrm{~s}$ as determined from the video.

\subsection{Impact zone water depth}

The water depth in the impact zone is one of the most important parameters which determines the type of the tsunami wave, and is the main reference parameter for the wave equations. Due to the dangerous proximity of the high and unstable ice cliff it was never directly measured, but can be inferred from the wave height.

The water depth in the impact zone can be estimated from the impact velocity $v_{\mathrm{s}} \sim 40 \mathrm{~m} \mathrm{~s}^{-1}$, the ice slide thickness $s \sim 50 \mathrm{~m}$, and the maximum amplitude of the tsunami wave $a_{\mathrm{M}}=45-50 \mathrm{~m}$. According to an empirically derived equation (Eq. (5) in Heller et al., 2009), these quantities are related by

$$
\frac{a_{\mathrm{M}}}{h_{0}}=\frac{4}{9} P^{\frac{4}{5}},
$$

where the impulse product parameter $P$ (defined in Eq. 7) is related to the slide momentum flux. This equation is satisfied for a water depth in the impact zone of $h_{0}=20-40 \mathrm{~m}$.

As an independent test of the water depth determined in this way, the wave celerity of a solitary wave can be used (Eq. 2). For the inferred water depth of $h_{0}=20-40 \mathrm{~m}$ this yields $c=26.2-29.7 \mathrm{~m} \mathrm{~s}^{-1}$ which is in good agreement with the wave celerity determined from the video.

\subsection{Tsunami wave height}

Figure 6 shows the record of a pressure sensor mounted on the shore opposite of the glacier where pressure data were sampled in a $5 \mathrm{~s}$ interval. The first tsunami wave attains a height above sea level of $3.3 \mathrm{~m}$ and the first trough is $-2.2 \mathrm{~m}$. 
Upon landfall on bedrock this wave reached heights above sea level far exceeding $10 \mathrm{~m}$, depending on the local geometry of the shore (own observations and accounts from several eyewitnesses).

The time difference between the first three wave maxima is 36 and $28 \mathrm{~s}$, and the delay between the two largest wave peaks is $127 \mathrm{~s}$.

The recorded wave signal is a superposition of waves traveling along different paths or with different speeds. A series of waves has been observed to follow the shore (east of glacier) with run-ups far exceeding $10 \mathrm{~m}$. Since these waves travel at considerably lower speed than the direct wave, the observed signal is likely due to reflections at the shoreline or frequency dispersion (e.g., Heller and Spinneken, 2015).

\section{Discussion}

Tsunami waves at the boat landing in the bay of Eqip Sermia, traditionally called de Quervain's Havn or Port Emile Victor, are not a new phenomenon. For example, Fig. 90 in Bauer (1955) shows a tsunami wave on the beach of the Eqe lagoon (located south of the glacier terminus). A recent phenomenon, however, is very high tsunami waves hitting the shore. Such very high waves running up more than $15 \mathrm{~m}$ above sea level were first observed in 2012, and in 2013 they destroyed the boat landing of the local tour operator (video on YouTube, http://www.youtube.com/watch? $\mathrm{v}=215 \mathrm{Da} 7 \mathrm{fIKtI}$ ). Currently, old vegetation including birch bushes high on the shores is eroded by tsunami waves (the aforementioned video and observations by the authors made in July 2014 and 2015; Fig. 7). This supports the notion that such high tsunami waves are a novel phenomenon on a decades-to-century timescale. Since collapses of the $200 \mathrm{~m}$ high glacier front cause the tsunami waves, we can infer that such a high ice cliff is a very recent phenomenon. Indeed, throughout the documented history of Eqip Sermia (since 1912), the maximum cliff height of the glacier was about $50 \mathrm{~m}$ (Lüthi et al., 2016), from which smaller tsunamis were triggered.

\subsection{Tsunami wave parameters}

In the following we characterize the observed tsunami wave with dimensionless numbers which allow us to test the consistency of observations further, and to predict the heights of the tsunami waves under likely future glacier terminus geometries. For the characterization of the observed tsunami we use empirical formulas for impulse wave parameters based on a wide range of laboratory experiments (Heller et al., 2009; Heller and Hager, 2010, 2011; Heller and Spinneken, 2015).

From the results presented above, several dimensionless parameters characterizing the tsunami wave can be derived, most of which contain the water depth in the impact area as a

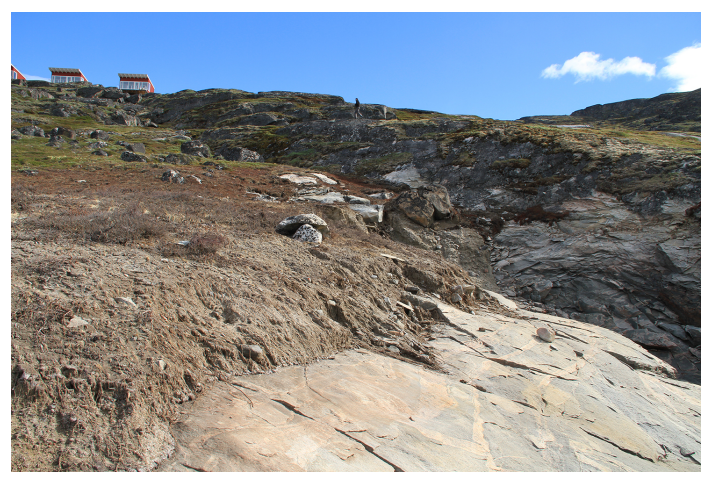

Figure 7. The tsunami waves lead to recent erosion of old vegetation on the shores.

reference parameter. This water depth is likely $h_{0}=20-40 \mathrm{~m}$ (Sect. 4.5).

With an ice slide thickness along the slide surface of $s=50 \mathrm{~m}$, the relative slide thickness is

$S=\frac{s}{h_{0}}=1.25-2.5$.

The relative slide mass, using the slide width $b=100 \mathrm{~m}$ (Fig. 4), the slide volume $V=9 \times 10^{5} \mathrm{~m}$, and the densities of glacier ice $\rho_{\mathrm{i}}=900 \mathrm{~kg} \mathrm{~m}^{-3}$ and water $\rho_{\mathrm{W}}=1000 \mathrm{~kg} \mathrm{~m}^{-3}$ amounts to

$M=\frac{m_{\mathrm{s}}}{\rho_{\mathrm{w}} b h_{0}^{2}}=\frac{\rho_{\mathrm{i}} V_{\mathrm{s}}}{\rho_{\mathrm{w}} b h_{0}^{2}}=5-20$.

The slide Froude number $F$ relates the slide impact velocity $v_{\mathrm{s}}$ to the shallow water wave celerity $c=\sqrt{g h}$ and is

$F=\frac{v_{\mathrm{s}}}{\sqrt{g h_{0}}}=2.1-3.0$.

These values show that the slide speed is "supersonic" for the given water depth. With the slide angle $\alpha=45^{\circ}$ we obtain the impulse product parameter $P$.

$P=F S^{0.5} M^{0.25}\left(\cos \left(\frac{6}{7} \alpha\right)\right)^{0.5}=3.1-8.9$

Equation (3) and the parameter $P$ were used to infer the water depth $h_{0}$ in the impact zone from the measured maximum wave amplitude. The distance from the terminus where the maximum wave amplitude is attained, however, is calculated to $330-390 \mathrm{~m}$, whereas the observations yield $\sim 260 \mathrm{~m}$. This difference might be due to a deepening of the bathymetry away from the glacier terminus (Lüthi et al., 2016), and thus reduced wave heights there.

An alternative formulation for the maximum wave amplitude in 3-D (Eq. (5) in Heller and Spinneken, 2015) yields values that are an order of magnitude too high for the inferred impact zone water depth. Using this formula to infer water depth on the other hand yields $h_{0}=70-80 \mathrm{~m}$, which, however, leads to higher values of wave speeds, smaller values 
of far-field wave heights, and different wave type parameters (cnoidal instead of bore-like) than observed.

The tsunami wave height at the tide gauge in a distance of $r=4550 \mathrm{~m}$ from the impact area is theoretically (Heller and Spinneken, 2015, Eq. 9)

$H=2.75 F^{0.67} S M^{0.6}\left(\frac{r}{h_{0}}\right)^{-1} f_{\gamma}=5.3-7.6 \mathrm{~m}$,

for the direction angle $\gamma=0$ of the tide gauge with respect to the wave source, and with $f_{\gamma}$ a direction-dependent factor. At an angle of $\gamma=30^{\circ}$ the wave amplitudes are reduced by $6 \%$ to $H=5.0-7.2 \mathrm{~m}$. The alternative formulation (Heller et al., 2009, Eq. 3.13) yields

$H=\frac{3}{2} P^{\frac{4}{5}} \cos ^{2}\left(\frac{2 \gamma}{3}\right)\left(\frac{r}{h_{0}}\right)^{-\frac{2}{3}} h_{0}=4.6-6.4 \mathrm{~m}$,

and $4.0-5.6 \mathrm{~m}$ for $\gamma=30^{\circ}$. These wave heights are again in reasonable agreement with the $5.5 \mathrm{~m}$ (maximum to minimum) observed at the tide gauge.

Finally, we determine the wave type parameter (Heller and Hager, 2011):

$T=S^{\frac{1}{3}} M \cos \left(\frac{6}{7} \alpha\right)=4-21$.

Such high values of $T$ are characteristic of bore-like waves (Fig. 2 in Heller and Hager, 2011). The observed wave clearly fits into this category (Fig. 5).

The above dimensionless numbers are relatively high, but still within the limits of validity given in Heller et al. (2009) and Heller and Hager (2010) for the experimental results from physical models. The reason for this is the very shallow impact zone compared to the slide thickness. The current geometry at Eqip Sermia leads to large values of the relative slide thickness $S$ and the relative slide mass $M$, and thus to high values of the dimensionless numbers $P$ and $T$, and the derived quantities like maximum wave height $H_{\mathrm{M}}$ and wave height $H$ in the impact zone.

\subsection{Future danger potential}

An important practical question arises concerning the future prospects of tsunami wave heights in the boat landing area, i.e., whether future tsunami waves could reach higher on the shores than at present. It is likely that under the current evolution of the Eqip Sermia glacier the calving front will further retreat. Without thinning of the glacier this would further increase the height of the calving front, and therefore lead to higher waves, and consequently higher tsunami wave runups on the shores. As an extreme limiting case, increasing the calving cliff height from the present 200 to $300 \mathrm{~m}$, while leaving all other quantities equal, would lead to maximum wave heights of $60 \mathrm{~m}$ (from Eq. 3), and maximum tsunami wave heights at the shore of $6 \mathrm{~m}$ instead of the present $5 \mathrm{~m}$ (from Eq. 9). The effects on the shore with a $20 \%$ increase of wave heights, given a $50 \%$ increase of calving front height, are relatively modest. If, on the other hand, a $200 \mathrm{~m}$ calving front height can be sustained in deeper water, the tsunami waves will increase considerably in size. For example, with a depth of the impact zone of $h_{0}=100 \mathrm{~m}$ instead of the current 20-40 m (leaving all other quantities equal), the maximum wave amplitude will decrease by $20 \%$, while the tsunami wave close to the shore will increase from 5 to $10 \mathrm{~m}$. A further possible change could affect the slide thickness. For a double thickness of $s=100 \mathrm{~m}$ the maximum wave height would increase to $62-67 \mathrm{~m}$, and the maximum tsunami wave heights on the shore would increase to 6-7 m.

These calculations show that under the present mode of calving with ice cliff collapses, only moderate increases in tsunami wave heights are to be expected, unless the calving front retreats into deeper water while maintaining its height.

The probable longer term evolution of the terminus is less clear. As the glacier will likely recede into an over-deepened basin, increasing longitudinal strain rates will reduce the ice thickness of the frontal part. Thinner ice in this area will reduce the calving front height and therefore the danger from tsunamis. Upon further retreat, other modes of calving might likely become important. If large chunks of ice break off and rotate, as has been observed at Jakobshavn Isbræ (among several other glaciers), high waves of tens of meters' initial amplitude are likely (Lüthi et al., 2009). If such waves will lead to similar-size tsunamis is unclear, but they might be restricted to smaller wave heights (MacAyeal et al., 2011). Given that the highest waves measured within the Kangia fjord at a distance of $3 \mathrm{~km}$ from Jakobshavn Isbræ, although on the sides, are less than $2 \mathrm{~m}$ (Amundson et al., 2008, and unpublished data), the probability of very big calving waves exceeding the height of the presently observed ones is likely small.

\section{Conclusions}

Detailed observations of landslide-generated tsunamis are scarce due to the rareness of such events. Data documenting the whole process chain are even more rare, as many such events happen without prior indication, or in areas that are not surveyed. Therefore, most knowledge on impulse waves has to be gained from laboratory studies with physical models (e.g., Fritz et al., 2003; Panizzo et al., 2005; Heller and Hager, 2010; Heller and Spinneken, 2015), or from numerical models (e.g., Pastor et al., 2009; Viroulet et al., 2013; Gabl et al., 2015). The results derived as a result might be challenged by scaling issues in the case of laboratory models, or by parametrization choices in the case of numerical models. Validation of such model results with data from realworld events is mandatory, but is only rarely possible due to lack of observations. 
Very high calving waves caused by a collapsing ice front have been observed at Eqip Sermia since 2012. In this publication we investigated a well-documented case from summer 2014, and analyzed characteristic quantities of the tsunami. With this data set we could perform a validation of the equations derived from physical models. All observed quantities agreed well with the values derived from empirical formulas in Heller et al. (2009) and Heller and Hager (2010), except for the observed wave period which likely is a superposition of dispersed or reflected waves.

Tsunami waves caused by calving glaciers pose a threat to infrastructure and boat traffic in waters hosting calving glaciers. Given the very rapid recent changes of oceanterminating glaciers in the Arctic, and their likely future changes (e.g., Moon et al., 2012; Nick et al., 2013), the geometries of tidewater glaciers might rapidly change, and lead to altered modes of calving. This could lead to changing heights and patterns of tsunami waves caused by glacier calving or rotating icebergs, and therefore pose new threats to coastal areas in narrow fjords, or in the vicinity of calving glaciers.

Acknowledgements. We thank Luc Moreau for his help in the field. Logistical support by World of Greenland, Flemming Bisgaard, and the Ilulissat Water Taxi is acknowledged. We thank Niels Engell and Erik Bak for publishing their videos on YouTube. This work was partially supported by the Swiss National Science Foundation grant 200021_156098. We acknowledge the insightful comments of five anonymous reviewers.

Edited by: D. M. Holland

\section{References}

Amundson, J. M., Truffer, M., Lüthi, M. P., Fahnestock, M., Motyka, R. J., and West, M.: Glacier, fjord, and seismic response to recent large calving events, Jakobshavn Isbræ, Greenland, Geophys. Res. Lett., 35, L22501, doi:10.1029/2008GL035281, 2008.

Amundson, J. M., Fahnestock, M., Truffer, M., Brown, J., Lüthi, M., and Motyka, R.: Ice mélange dynamics and implications for terminus stability, Jakobshavn Isbræ, Greenland, J. Geophys. Res., 115, F01005, doi:10.1029/2009JF001405, 2010.

Amundson, J. M., Clinton, J. F., Fahnestock, M., Truffer, M., Lüthi, M. P., and Motyka, R. J.: Observing calvinggenerated ocean waves with coastal broadband seismometers, Jakobshavn Isbræ, Greenland, Ann. Glaciol., 60, 79-84, doi:10.3189/2012/AoG60A200, 2012.

Bauer, A.: Glaciologie Groenland II. Le glacier de l'Eqe. 6, Tech. rep., Expéditions Polaires Francaises, Hermann, Paris, 118 pp., 1955.

Bauer, A.: Le glacier de l'Eqe (Eqip Sermia). Mouvement et variations du front (1959), Tech. Rep. 2, Expédition glaciologique internationale au Groenland (EGIG), Meddelelser om Grønland, Reitzel, København, 1968.
Benn, D. I., Warren, C. R., and Mottram, R. H.: Calving processes and the dynamics of calving glaciers, Earth-Sci. Rev., 82, 143179, doi:10.1016/j.earscirev.2007.02.002, 2007.

Caduff, R., Schlunegger, F., Kos, A., and Wiesmann, A.: A review of terrestrial radar interferometry for measuring surface change in the geosciences, Earth Surf. Proc. Land., 40, 208-228, doi:10.1002/esp.3656, 2014.

Ekström, G., Nettles, M., and Abers, G.: Glacial Earthquakes, Science, 302, 622-624, doi:10.1126/science.1088057, 2003.

Ekström, G., Nettles, M., and Tsai, V. C.: Seasonality and increasing frequency of Greenland glacial earthquakes, Science, 311, 17561758, doi:10.1126/science.1122112, 2006.

Fritz, H. M., Hager, W. H., and Minor, H.-E.: Landslide generated impulse waves. 1. Instantaneous flow fields, Exp. Fluids, 35, 505-519, doi:10.1007/s00348-003-0659-0, 2003.

Fritz, H. M., Hager, W. H., and Minor, H.-E.: Near field characteristics of landslide generated impulse waves, J. Waterway Port Coast. Ocean Eng., 130, 287-302, doi:10.1007/s00348-0030659-0, 2004.

Gabl, R., Seibl, J., Gems, B., and Aufleger, M.: 3-D-numerical approach to simulate the overtopping volume caused by an impulse wave comparable to avalanche impact in a reservoir, Nat. Hazards Earth Syst. Sci., 15, 2617-2630, doi:10.5194/nhess-152617-2015, 2015.

Heller, V. and Hager, W. H.: Impulse product parameter in landslide generated impulse waves, J. Waterway Port Coast. Ocean Eng., 136, 145-155, doi:10.1061/(asce)ww.1943-5460.0000037, 2010.

Heller, V. and Hager, W.: Wave types of landslide generated impulse waves, Ocean Eng., 38, 630-640, doi:10.1016/j.oceaneng.2010.12.010, 2011.

Heller, V. and Spinneken, J.: On the effect of the water body geometry on landslide-tsunamis: Physical insight from laboratory tests and 2D to 3D wave parameter transformation, Coast. Eng., 104, 113-134, doi:10.1016/j.coastaleng.2015.06.006, 2015.

Heller, V., Hager, W. H., and Minor, H.-E.: Scale effects in subaerial landslide generated impulse waves, Exp. Fluids, 44, 691-703, doi:10.1007/s00348-007-0427-7, 2008.

Heller, V., Hager, W. H., and Minor, H.-E.: Landslide generated impulse waves in reservoirs: Basics and computation, Mitteilungen 211, Versuchsanstalt für Wasserbau, Hydrologie und Glaziologie der ETH Zürich, Zürich, Switzerland, 172 pp., 2009.

Howat, I., Negrete, A., and Smith, B.: The Greenland Ice Mapping Project (GIMP) land classification and surface elevation datasets, The Cryosphere, 8, 1-26, doi:10.5194/tc-8-1509-2014, 2014.

Levermann, A.: When glacial giants roll over, Nature, 472, 43-44, doi:10.1038/472043a, 2011.

Lüthi, M. P., Fahnestock, M., and Truffer, M.: Calving icebergs indicate a thick layer of temperate ice at the base of Jakobshavn Isbræ, Greenland, J. Glaciol., 55, 563-566, doi:10.3189/002214309788816650, 2009.

Lüthi, M. P., Vieli, A., Moreau, L., Joughin, I., Reisser, M., Small, D., and Stober, M.: A century of geometry and velocity evolution at Eqip Sermia, West Greenland, J. Glaciol., doi:10.1017/jog.2016.38, in press, 2016.

MacAyeal, D. R., Abbot, D. S., and Sergienko, O. V.: Iceberg-capsize tsunamigenesis, Ann. Glaciol., 52, 51-56, doi:10.3189/172756411797252103, 2011. 
Moon, T., Joughin, I., Smith, B., and Howat, I.: 21st-century evolution of Greenland outlet glacier velocities, Science, 336, 576578, doi:10.1126/science.1219985, 2012.

Nettles, M., Larsen, T. B., Elosegui, P., Hamilton, G. S., Stearns, L. A., Ahlstrøm, A. P., Davis, J. L., Andersen, M. L., de Juan, J., Khan, S. A., Stenseng, L., Ekstrøm, G., and Forsberg, R.: Step-wise changes in glacier flow speed coincide with calving and glacial earthquakes at Helheim Glacier, Greenland, Geophys. Res. Lett., 35, L24503, doi:10.1029/2008GL036127, 2008.

Nick, F., Vieli, A., Vieli, A., Andersen, M. L., Joughin, I., Payne, A., Edwards, T., Pattyn, F., and van de Wal, R.: Future sea-level rise from Greenland's main outlet glaciers in a warming climate, Nature, 479, 235-238, doi:10.1038/nature12068, 2013.

Panizzo, A., Girolamo, P. D., and Petaccia, A.: Forecasting impulse waves generated by subaerial landslides, J. Geophys. Res., 110, C12025, doi:10.1029/2004JC002778, 2005.

Pastor, M., Herreros, I., Merodo, J. F., Mira, P., Haddad, B., Quecedo, M., González, E., Alvarez-Cedrón, C., and Drempetic, V.: Modelling of fast catastrophic landslides and impulse waves induced by them in fjords, lakes and reservoirs, Eng. Geol., 109, 124-134, doi:10.1016/j.enggeo.2008.10.006, 2009.

Reeh, N.: Long calving waves, in: Proceedings, 8th International Conference on Port and Ocean Engineering under Arctic Conditions, 7-14 September 1985, Narssarssuaq, 1310-1327, 1985.
Schulson, E. M. and Fortt, A. L.: Friction of ice on ice, J. Geophys. Res., 117, B12204, doi:10.1029/2012JB009219, 2012.

Strozzi, T., Werner, C., Wiesmann, A., and Wegmüller, U.: Topography Mapping With a Portable Real-Aperture Radar Interferometer, IEEE Geosci. Remote Sens. Lett., 9, 277-281, doi:10.1109/LGRS.2011.2166751, 2012.

Viroulet, S., Cébron, D., Kimmoun, O., and Kharif, C.: Shallow water waves generated by subaerial solid landslides, Geophys. J. Int., 193, 747-762, doi:10.1093/gji/ggs133, 2013.

Walder, J. S., Watts, P., Sorensen, O. E., and Janssen, K.: Tsunamis generated by subaerial mass flows, J. Geophys. Res., 108, 2236, doi:10.1029/2001JB000707, 2003.

Walter, F., Amundson, J., O’Neel, S., Truffer, M., Fahnestock, M., and Fricker, H.: Analysis of low-frequency seismic signals generated during a multiple-iceberg calving event at Jakobshavn Isbræ, Greenland, J. Geophys. Res., 117, F01036, doi:10.1029/2011JF002132, 2012.

Walter, F., Olivieri, M., and Clinton, J.: Calving event detection by observation of seiche effects on the Greenland fjords, J. Glaciol., 59, 162-178, doi:10.3189/2013JoG12J118, 2013. 